\title{
PENGGUNAAN DATA DEM SRTM UNTUK PEMETAAN DAERAH RAWAN \\ BANJIR DI KECAMATAN LHOKSUKON KABUPATEN ACEH UTARA
}

(USE OF DEMOGRAPHIC DATA FOR MAPPING FLOOD-PRONE AREAS IN LHOKSUKON SUB-DISTRICT, NORTH ACEH REGENCY)

\author{
Roby Arnando ${ }^{1}$, Muhammad Rusdi ${ }^{1}$, Hairul Basri ${ }^{1 *}$ \\ ${ }^{1}$ Program Studi Ilmu Tanah, Fakultas Pertanian, Universitas Syiah Kuala \\ *Corresponding author: hairulbasri@ unsyiah.ac.id
}

\begin{abstract}
Abstrak. Banjir merupakan masalah umum di sebagian daerah yang ada di Indonesia, terutama pada daerah yang memiliki topografi yang rendah di bagian hilir sungai. Penelitian ini bertujuan untuk melihat daerah yang sering dilanda banjir dengan hubungan peta daerah rawan banjir di Kecamatan Lhoksukon Kabupaten Aceh Utara. Kondisi topografi Kecamatan Lhoksukon dengan kelandaian yang curam dibagian hulu namun landai dibagian hilir, sehingga keadaan topografi ini dapat menyebabkan aliran air mengalir dengan kecepatan yang rendah pada daerah hilir. Keadaan topografi tersebut menggambarkan bahwa secara fisik Kecamatan Lhoksukon merupakan daerah yang rawan terhadap banjir. Berdasarkan hasil analisis kerawanan banjir di Kecamatan Lhoksukon dibagi 3 kelas yaitu kelas kerawanan sangat rawan banjir diperoleh 642,30 hektar, kelas rawan banjir 11.544,70 hektar dan kelas tidak rawan banjir seluas 1.542,57 hektar.
\end{abstract}

Kata kunci: Lhoksukon, Daerah Rawan Banjir, ArcGIS

\begin{abstract}
Flooding is a common problem in some regions in Indonesia, especially in areas that have low topography in the downstream river. This study aims to look at areas that are often hit by floods with the floodprone areas in Lhoksukon Sub District, North Aceh District. The topographic condition of Lhoksukon District is which steep slope in upstream but sloping in the downstream, so that topography can caused run off at a low speed in the downstream area. The topographical situation illustrates that physically Lhoksukon District is an area prone to flooding. Based on the results of the analysis of flood vulnerability in Lhoksukon Sub District divided into 3 classes: 642.30 ha of highly hazard-prone, 11,544.70 ha of flood-prone and 1,542.57 ha of nonflood-prone.
\end{abstract}

Keywords: Lhoksukon, Flood Prone Areas, ArcGIS

\section{PENDAHULUAN}

Banjir merupakan salah satu bencana alam yang memberikan dampak langsung terhadap kehidupan seperti kerusakan lingkungan, kerugian harta benda, dampak psikologis hingga timbulnya korban jiwa (Undang Undang Republik Indonesia No 24 Tahun 2007). Secara umum faktor penyebab banjir dapat di bagi menjadi 3 elemen seperti elemen meteorology, kharakteristik DAS (daerah aliran sungai) dan manusia.

Kecamatan Lhoksukon Kabupaten Aceh Utara merupakan daerah yang tergolong sering terjadi bencana banjir. Menurut laporan BNPBD (badan penanggulangan bencana daerah) Aceh Utara melaporakan bahwa pada tahun 2018 beberapa desa di Kecamatan Lhokuskon telah dilanda banjir sebanyak 17 Desa.

Penelitian ini bertujuan untuk melihat kelas kerawan banjir berdasarkan parameter kelerengan dan ketinggian tempat di Kecamatan Lhoksukon. Penelitian ini dilakukan secara spasial dengan memanfaatkan software ArcGIS 10.4, Global Mapper dan SAS Planet yang mengahasilkan sebuah peta kerawanan banjir. Peta kerawanan banjir merupakan bagian dari sistem peringatan dini (early warning system) dari bahaya dan resiko banjir sehingga akibat dari bencana banjir dapat diperkirakan dan pada akhirnya dapat diminimalisir. Peta tingkat kerawanan banjir yang baik adalah peta yang memiliki tingkat akurasi yang tinggi. Peta tersebut diperoleh dengan menggunakan teknik SIG berdasarkan metode penilaian, pembobotan dan proses tumpang susun (overlay) berdasarkan parmeter yang 
mempengaruhinya. Teknik SIG ini mempunyai kelebihan dalam hal kecepatan pemrosesan, kemudahan dalam penyajian, lebih efektif dan efisien serta akurat bila dibandingkan dengan pengerjaan secara manual (Suhardiman, 2012).

Mengingat besarnya debit banjir yang terjadi, menimbulkan genangan yang cukup besar serta merugikan sektor ekonomi Kecamatan Lhoksukon, maka perlu dilakukan upaya pencegahan atau pengurangan dampak dari bencana banjir. Salah satu upaya yang dapat dilakukan adalah dengan melakukan kajian Sistem Informasi Geografis (SIG) yaitu suatu sistem informasi berbasis komputer yang digunakan untuk mengolah dan menyimpan data informasi geografis (Suherlan, 2001).

\section{METODE PENELITIAN}

Lokasi penelitian ini di Kecamatan Lhoksukon yang merupakan salah satu kecamatan di Kabupaten Aceh Utara Provinsi Aceh. Secara geografis Kecamatan Lhoksukon terletak pada koordinat $4^{0} 57^{\prime}-5^{0} 7^{\prime}$ LU dan $97^{0} 17^{\prime}-97^{0} 26^{\prime}$ BT. Secara administrasi Kecamatan Lhoksukon berbatasan sebelah utara dengan Kecamatan Tanah Pasir dan Kecamatan Baktya, sebelah selatan berbatasan dengan Kecamatan Cot Girek, sebelah barat berbatasan dengan Kecamatan Matangkuli dan Kecamatan Tanah Luas dan sebelah timur berbatasan dengan Kecamatan Baktya, Kecamatan Tanah Luas (Lhoksukon Dalam Angka, 2018). Pengolahan data dan pembuatan peta daerah rawan banjir dilakukan di Laboratorium GIS and Remote Sensing Development Center Program Studi Ilmu Tanah Fakultas Pertanian Universitas Syiah Kuala, Banda Aceh. Kawasan kajian dapat dilihat pada Gambar 1.

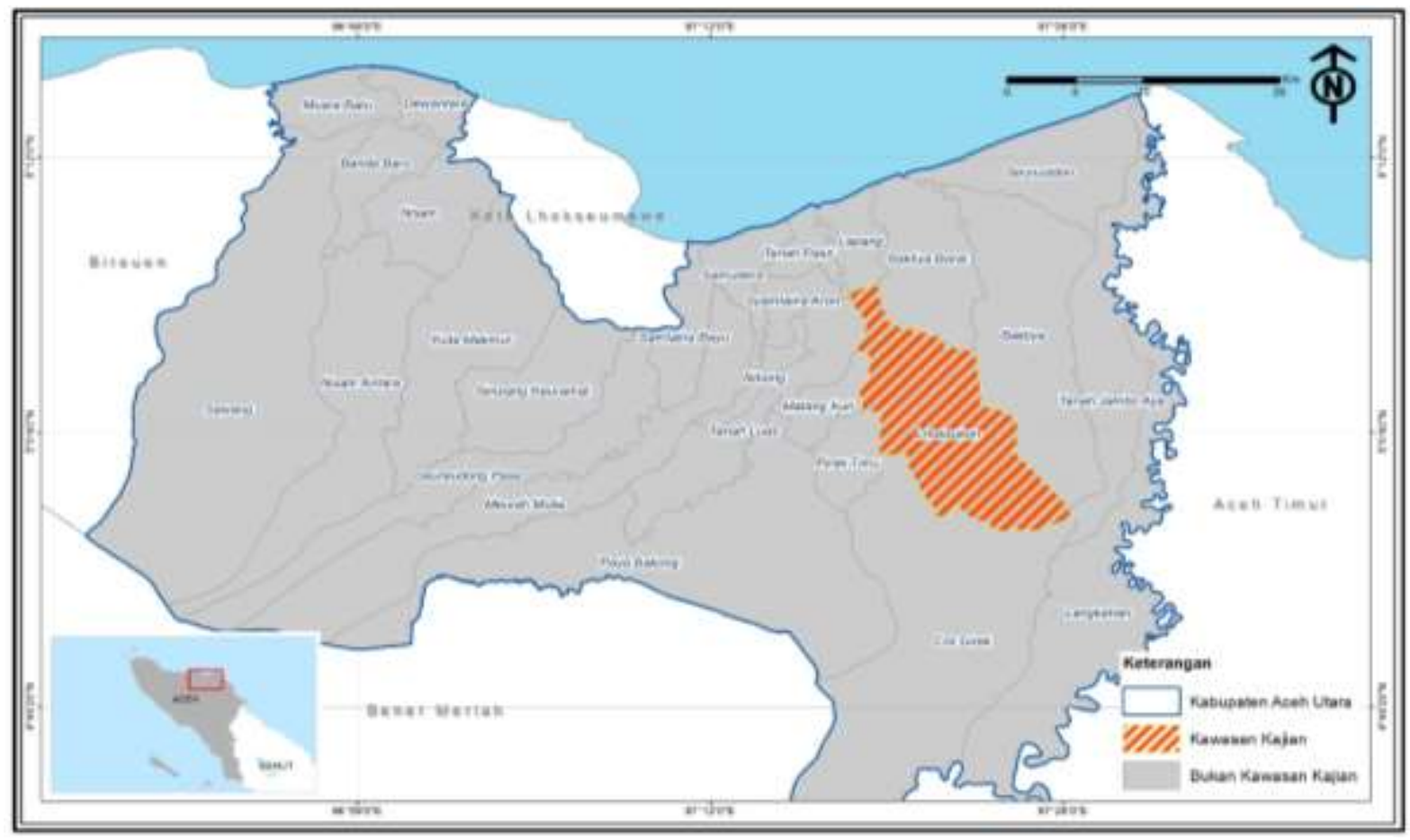

Gambar 1. Peta Kawasan Kajian

Ketinggian tempat berpengaruh untuk terjadinya bahaya bencana banjir yang mana semakin tinggi suatu tempat maka peluang untuk terjadinya banjir semakin rendah dan begitu juga dengan sebaliknya, semakin rendah suatu tempat maka peluang untuk terjadi bahaya bencana banjir akan semakin tinggi. 


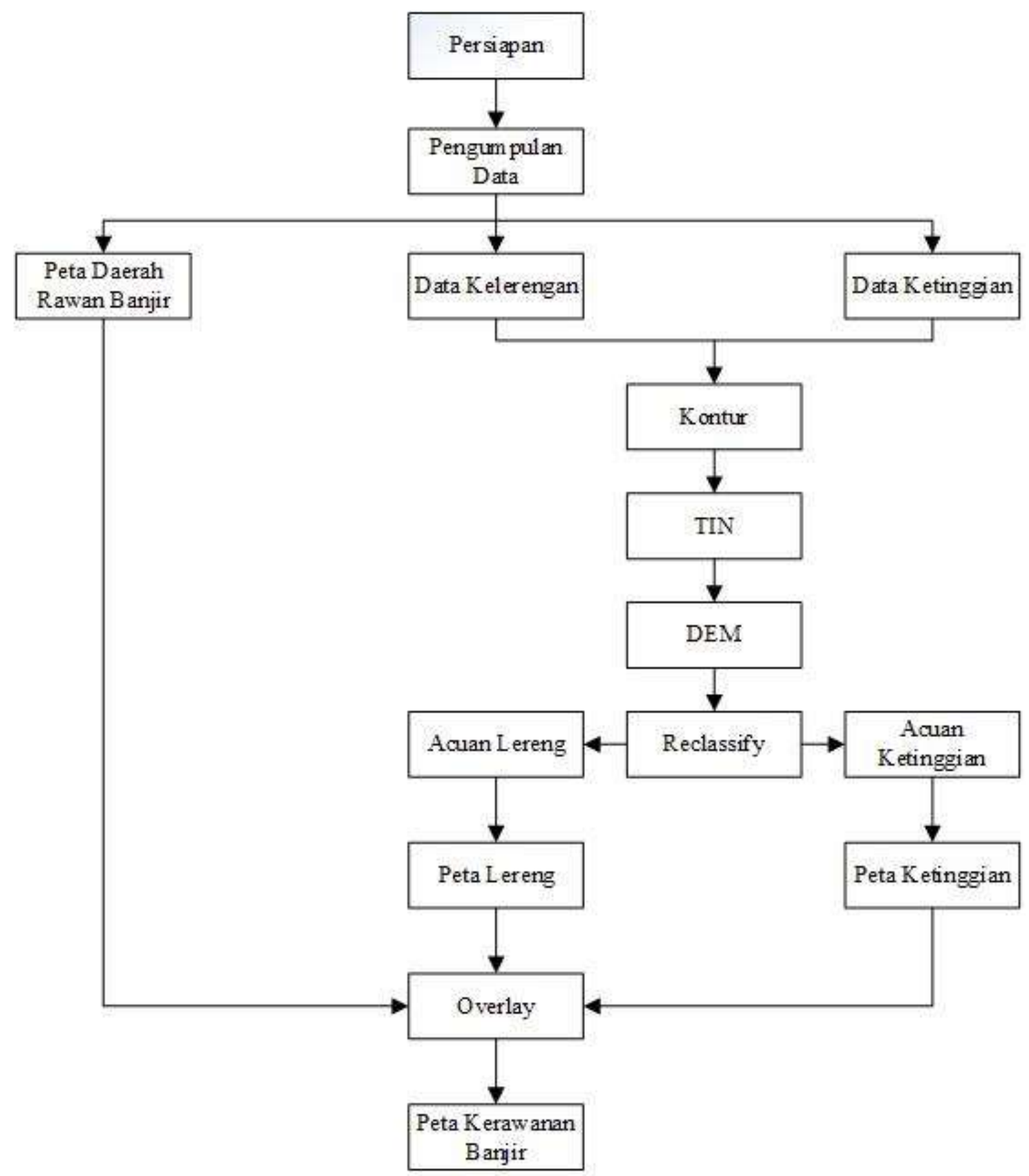

Gambar 2. Diagram Alir Penelitian

\section{HASIL DAN PEMBAHASAN}

Sangat rawan banjir adalah daerah yang sangat rentan dan kritis terhadap bahaya bencana banjir, daerah ini merupakan yang memiliki dataran rendah dan berada di hilir DAS. Curah hujan yang tinggi dan vegetasi yang tergolong rendah serta sebagian besar wilayahnya 
adalah wilayah terbangun sehingga menyebabkan tingginya aliran permukaan yang langsung mengalir ke sungai dan terjadilah bencana banjir. Berdasarkan hasil analisis daerah yang yang tergolong sangat rawan banjir memiliki luas 642,30 hektar.

Kelas sangat rawan banjir Kecamatan Lhoksukon ini dominan berada pada jenis tanah Inceptisol, dengan tekstur tanah yang halus dan tidak jauh dari sungai Krueng Keureuto juga merupakan daerah terbangun atau tergolong vegetasi yang rendah, maka daerah ini tergolong sangat rawan banjir. Keadaan topografi pada daerah yang sangat rawan banjir relatif rendah yaitu memiliki ketinggian di bawah 20 mdpl dengan kelerengan di bawah $13 \%$.

Rawan banjir merupakan kelas yang sudah tergolong potesnsial kritis terhadap bahaya bencana banjir. Daerah ini berada di dataran rendah dan penggunaan lahan yang didominasi oleh sawah. Banjir yang terjadi pada daerah ini biasanya tidak terlalu tinggi, dan bersifat genangan sementara yang diakibatkan curah hujan tinggi dan drainase yang buruk. Berdasarkan hasil analisis yang tergolong rawan banjir memiliki luas sebesar $11.544,70$ hektar.

Daerah yang termasuk sangat rawan dan rawan banjir merupakan daerah yang sering terjadi banjir namun yang membedakan adalah pada daerah yang tergolong rawan banjir air akan lebih cepat surut. Jika daerah rawan banjir dan sangat rawan banjir digabungkan maka luas daerah yang rawan terhadap banjir di Kecamatan Lhoksukon mencapai 12.187 hektar atau $89 \%$ dari luas Kecamatan Lhoksukon.

Kelas tidak rawan banjir merupakan kelas yang paling aman dari ancaman bencana banjir atau dapat juga dikatakan daerah yang kurang rentan terjadi bencana banjir. Hal ini bisa disebabkan karena daerah yang jauh dari sungai dan termasuk dataran tinggi serta penggunaan lahan yang masih banyak vegetasinya. Berdasarkan hasil analisis pada Kecamatan Lhoksukon tingkat kerawanan banjir yang tergolong tidak rawan tersebar seluas 1.542,57 hektar atau 11\% dari luas Kecamatan Lhoksukon. Hasil kajian daerah rawan banjir dapat di Gambar 3.

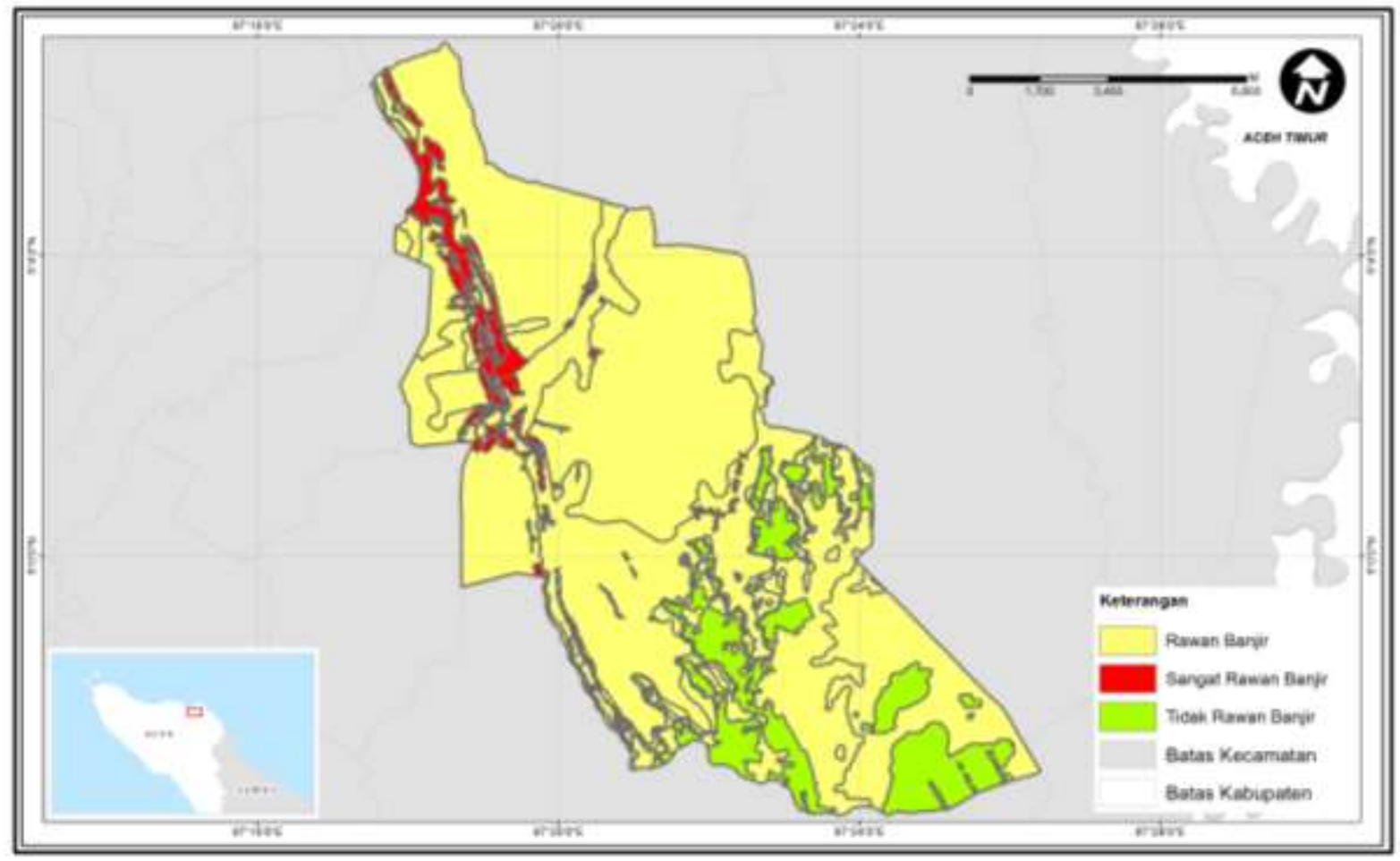

Gambar 3. Peta Daerah Rawan Banjir 


\section{KESIMPULAN DAN SARAN}

Tingkat Kerentanan banjir di Kecamatan Lhoksukon terdiri dari 3 kelas yaitu kelas tidak rawan banjir yang tersebar seluas 1.542,57 hektar, kelas rawan banjir seluas 11.544,70 hektar dan kelas sangat rawan banjir seluas 642,30 hektar. Daerah rawan dan sangat rawan banjir jika digabung maka diperoleh luas daerah yang tergolong rawan banjir di Kecamatan Lhoksukon mencapai 12.187 hektar atau 89\% dari total luas Kecamatan Lhoksukon.

Perlu adanya penambahan luas area penelitian tingkat Kabupaten untuk melihat daerah yang sering dilanda banjir di Kabupaten Aceh Utara serta Perlu menvalidasi data administrasi (Desa, Kecamatan dan Kabupaten) serta data bencana banjir yang pernah terjadi karena data yang dikeluarkan oleh instansi terkait beragam.

\section{DAFTAR PUSTAKA}

BPS. 2018. Kecamatan Lhoksukon dalam Angka, Kabupaten Aceh Utara 2018. BPS Kabupaten Aceh Utara, Provinsi Aceh.

Suhardiman. 2012. Zonasi Tingkat Kerawanan Banjir dengan Sistem Informasi Geografis (SIG) pada Sub DAS Walanae Hilir. Skripsi. Jurusan Tegnologi Pertanian Fakultas Pertanian Universitas Hasanuddin, Makassar.

Suherlan, E. 2001. Zonasi Tingkat Kerentangan Banjir Kabupaten Bandung Mengunakan Sistem Informasi Geografis. Skripsi. Institut Pertanian Bogor.

Undang Undang Republik Indonesia Nomor 24 Tahun 2007 Tentang Penanggulangan Bencana. 